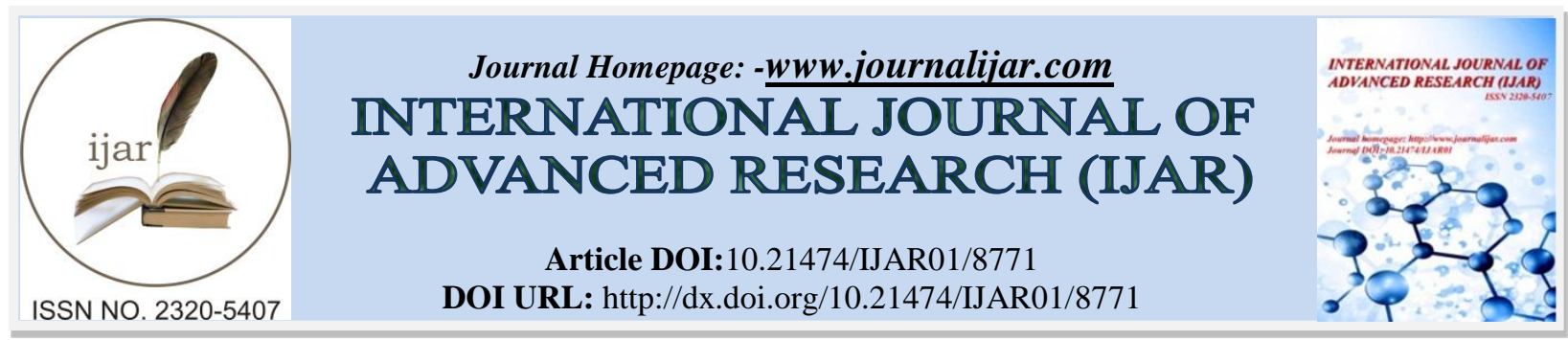

RESEARCH ARTICLE

\title{
STUDY ON FOOD CHOICE MOTIVES FOR PURCHASING ORGANIC PRODUCE WITH REFERENCE TO PUNE.
}

\author{
Kajal Maheshwari And Anuradha Phadnis. \\ Assistant Professor,S.B. Patil Institute of Management, Pune (India) Postal Address: Sector No. 26, Near Akurdi \\ Railway Station, Nigdi, Pradhikaran, and Pune 44.
}

\section{Manuscript Info}

Manuscript History

Received: 20 January 2019

Final Accepted: 22 February 2019

Published: March 2019

Key words:-

Organic Produce, Pune, Marketing, Marketing Strategies.

\begin{abstract}
Maharashtra is the third largest State by area in India after Rajasthan and Madhya Pradesh, located in the North centre of Indian peninsula. Organic farming is at present a movement in Maharashtra. These organic growers tend to supply directly to consumers or retailers thus cutting out the middlemen and avoid the excessive handling of perishable commodities. It also helps in raising the profitability of the venture. Though the market potential of this business is huge, it is faced with the situation where the buyer does not know where to buy and the grower does not know how to sell. Availability of sourcing reliable produces that to consistently is the biggest challenge. Certification is the solution to ensure quality and establish trust, but it is costly. In this paper researcher tries to find the reasons why customers are not buying Organic Food. Results shown that customers are concerned on trust (originality), convenience purchasing, non-availability of variety are the major reasons of buying organic produce. In this paper strategies are suggested to overcome these challenges.
\end{abstract}

Copy Right, IJAR, 2019,. All rights reserved.

\section{Introduction:-}

The present agricultural sector influences the development of the Indian economy. Agriculture (including other allied activities) accounted for 15.7 per cent of the Gross Domestic Product (GDP-at constant prices) in 2008-09 as compared to 21.7 per cent in 2003-04. In spite of the fact that the share of farming sector in GDP has been falling over the years, but its role remains critical as it accounts for about 52 percent of the employment in the country. Agricultural sector also contributed 10.2 per cent of national exports in 2008-09 (Economic Survey, 2009-10). Agriculture provides food for more than one billion people and yields raw materials for agro-based industries. Transformation of Indian agriculture has begun during the mid-sixties which resulted in the, Green Revolution making the country a food grain surplus nation from a deficit, one depending on food imports. But, modern agriculture has returned several problems besides creating a very unsustainable system for mankind (Worthington, 1980). Cultivation of crops became more dependent on inputs purchased from the market, and farmers began to sell a superior share of the crop in the market. The rising costs of cultivation and uncertain output prices made the modern agriculture system non-viable

Corresponding Author:-Kajal Maheshwari.

Address:-Assistant Professor,S.B. Patil Institute of Management, Pune (India) Postal Address:

Sector No. 26, Near Akurdi Railway Station, Nigdi, Pradhikaran, and Pune 44. food grain $\mathrm{e}$ in the net ased use of 
inputs like fertilizers, pesticides and farm machinery. As time went by, extensive need on chemical farming has shown its darker side. The land is losing its fertility and is demanding larger quantities of fertilizers. Pests are becoming resistant and warrant frequent sprays resulted in residues much above the safety levels and this brought to the attention of modern agriculture and cemented the way for organic farming in India.

\section{Literature review \\ Barriers to purchase \\ Availability \& Range of Organic Product}

(Grunert, 1995)(Arvola, 2008)(Bellows, 2008) (Padel, 2005)

Consumers who do not buy organic food items, research was done to understand major barriers to purchasing organic food related to range and availability. Organic growth has been primarily demand-led (Latacz-Lohmann, 1997), which meant particularly historically, that many consumers face availability issues, or severely limited ranges of organic products.

(Pierce, 3 August 2009)

So, some locations in more affluent areas are designed to carry more organic produce, while some stores is less affluent areas might not carry any organic products at all.

(Fotopoulos C. a., 2000)

As food items are perceived as low involvement products customers do not want to take much efforts while purchasing them but extensive review of the literature on this subject revealed substantially less attention has been paid to measuring the effort consumers are willing to go to in order to purchase organic products.

(Bourn, 2002)

Researcher also supports the above study by highlighting the nutritive, sensory and food safety as the points of comparison between organic and inorganic food.

\section{Appearance}

(Beharrell, 1991)

According to the research done by researcher some consumers choose organic food because of taste, freshness and its appearance On the other hand some literatures have shown contradictory results.

\section{(Lin, 1986)}

In this researcher found that consumers considered appearance less important when they buy organic food items.

\section{No Difference in Taste}

(Jolly, 1991), (Sparling, 1992)

In some of the research researcher do not find any difference in the taste of organic food and inorganic food. Therefore, researcher decides to test this phenomenon.

\section{Availability}

(Dettmann, 2007)

Increased marketing of organic products through conventional supermarkets and large retail outlets in addition to the traditional venues of specialty stores, have made organic produce accessible to more consumers.

\section{High Price}

(Padel, 2005) (Zanoli, 2004)

The price of organic food is playing a major part in the purchasing intentions and behaviour of consumers. They are acting as a barrier, due to price premiums of organic produce vs. conventional. In fact, the price of organic food has been cited in many articles to be the main obstacle for not buying organic food items.

\section{Summarising Consumer Behaviour Literature}


When it comes to decision making the motives and motivation hold a high explanatory degree. Furthermore, much literature revolves around the concepts of quality in terms of rich in nutrients and health as the most important consequences for consumers when choosing their foods in general.

The high focus on health has increased the focus on extrinsic quality cues in general and will continue to do so in the future according to the literature available.

\section{Objectives Of The Study}

1. To examine the factors affecting consumer decision making for organic food items.

2. To study the customer satisfaction level w.r.t. marketing mix.

\section{Hypothesis Of The Study}

Hypothesis 1:-

Difficulties in identifying real organic, non-availability, Brand awareness are the major reasons for not buying organic food items.

\section{Hypothesis 2:-}

Customers are dissatisfied with respect to the elements of marketing mix (4P's) of organic food items.

\section{Time Horizon}

The time horizon is used in this research to collect the data from July 14 to January 15.

\section{Primary Method of Data Collection}

Questionnaires:

The data was collected through self-administered questionnaires which were distributed to the buyers and nonbuyers of organic produce in Pune region.

\section{Interviews:}

Discussion was also done with buyers \& non buyers of organic produce to understand buying behaviour pattern for household grocery items

\section{Secondary Method of Data Collection}

The secondary data was collected from: Books, reports, newspaper article, e- journals, journals, research papers, websites, and publications- periodicals.

\section{Sample size:}

The study is focused in Maharashtra, Pune Region. A total of 451 respondents participated in the survey.

\section{Hypothesis1}

Difficulties in identifying real organic, non-availability, Brand awareness are the major reasons for not buying organic food items.

In order to test above hypothesis following sub hypotheses are created and tested statistically.

\section{H1a:}

There is a significant difference in the importance customer attached to the various reasons for not buying organic products

\section{Reasons for Not Consuming Organic Food Items}

\section{Research Question:}

Is there a difference in the importance customer attached to the various reasons for not buying organic products.

\section{Research Tools:}

Friedman Chi Square Test

\section{Variable \&Measurements:}


Respondents were presented with following eleven reasons for not purchasing of organic food items. Each reason were measured on 5- Point Likert scale $(1=$ Strongly Disagree, $2=$ Disagree, $3=$ Neutral, $4=$ Agree, $5=$ Strongly Agree)

1. No difference in taste of organic \& Conventional

2. No difference in nutrition value

3. Presence of unsafe harmful bacteria and organism

4. Too expensive

5. Not easily available in the shop

6. No Perceived health benefits

7. Source of organic is not trustable

8. Bad in appearance

9. No enough choice (assortment)

10. Do not know the brand

11. Difficult to identify real organic

H0:

There is no difference in the importance customer attached to the various reasons for not buying organic products.

H1:

There is a significant difference in the importance customer attached to the various reasons for not buying organic products.

Level of Significance $=0.05$

Table 1:-Test Statistics of Reasons for Never Consuming Organic Food Items

\begin{tabular}{|l|c|}
\hline $\mathrm{N}$ & 59 \\
\hline Chi-Square & 183.214 \\
\hline $\mathrm{df}$ & 10 \\
\hline Asymp. Sig. & .000 \\
\hline
\end{tabular}

\section{Observation:}

$\chi^{2}(10)=183.214, \mathrm{P}=0.000, \mathrm{~N}=59$

\section{Conclusion:}

Since $\mathrm{P}$ value $(0.000)$ is less than the level of significance $(0.05)$ the null hypothesis is rejected.

Hence it is concluded that there is a significant difference in the importance customer attached to the various reasons for not buying organic products

In order to find where the difference lies we refer to the Ranks Table

Table1.2:-Ranks Table of Reasons for Never Consuming Organic Food

\begin{tabular}{|l|c|}
\hline Reason for never consuming & Mean Rank \\
\hline No difference in taste of organic \& Conventional & 3.97 \\
\hline No difference in nutrition value & 5.21 \\
\hline Presence of unsafe / harmful bacteria and organism & 3.97 \\
\hline Too expensive & 6.58 \\
\hline Not easily available in the shop & 8.52 \\
\hline No Perceived health benefits & 4.83 \\
\hline Source of organic is not trustable & 6.01 \\
\hline Bad in appearance & 4.34 \\
\hline No enough choice (assortment) & 6.75 \\
\hline Do not know the brand & 7.31 \\
\hline Difficult to identify real organic & 8.52 \\
\hline
\end{tabular}

Source: Field Survey

Interpretation: 
From the Ranks Table it can be seen "No difference in taste of organic \& Conventional" has a mean rank of 3.97," No difference in nutrition value" has a mean rank of 5.21, "Presence of unsafe/ harmful bacteria and organism" has a mean rank of 3.97, "Too expensive" has a mean rank of 6.58, "Not easily available in the shop" has a mean rank of 8.52, "No Perceived health benefits" has a mean rank of 4.83 , "Source of organic is not trustable" has a mean rank of 6.01, "Bad in appearance" has a mean rank of 4.34, "No enough choice (assortment) "has a mean rank of 6.75 , "Do not know the brand" has a mean rank of 7.31, "Difficult to identify real organic" has a mean rank of 8.52 .

\section{Conclusion of Hypothesis:}

Hence it can be concluded that the top six reasons (Strong Predictor) for not buying organic food items are: Difficulty in identifying real organic, not easily available in the shop, do not know the brand, No enough choice (assortment), too expensive, Source of organic is not trustable. Hence sub hypothesis H1a is proved.

Therefore hypothesis is proved, Difficulty in identifying real organic, Non availability, Brand awareness are the major reasons for not buying organic food items.

\section{Hypothesis-2 Customers are dissatisfied with respect to the elements of marketing mix (4P's) of organic food} items.

In order to test above hypothesis following sub hypotheses are created and tested statically.

\section{Ha:}

There is significant difference in the level of customers' satisfactions with respect to the elements of marketing mix of organic food item.

\section{Research Question:}

Is there a difference in the level of customers' satisfactions with respect to elements of marketing mix of organic food item.

\section{Statistical Test:}

Friedman Chi Square test

Variable \& Measurement: Respondent were presented with following five options

1. Freshness of Product

2. Packaging \& Labelling

3. Health benefits after consuming it

4. Communication

5. Delivery of Product

\section{H0:}

There is no difference in the level of customers' satisfactions with respect to the elements of marketing mix of organic food item.

\section{H1:}

There is significant difference in the level of customers' satisfactions with respect to the elements of marketing mix of organic food item.

\section{Level of Significance $\alpha=0.05$}

Table 2.1:-Test Statistics of Respondents satisfaction with 4P's of Marketing Mix

\begin{tabular}{|l|c|}
\hline \multicolumn{2}{|c|}{ Test Statistics $^{\text {a }}$} \\
\hline $\mathrm{N}$ & 202 \\
\hline Chi-Square & 144.360 \\
\hline df & 4 \\
\hline Asymp. Sig. & .000 \\
\hline
\end{tabular}

\section{Observation:}


$\chi^{2}(4)=144.360, P=0.000, \mathrm{~N}=202$

\section{Conclusion:}

Since the $\mathrm{P}$ value (0.000) is less than the level of significance $(0.05)$ the null hypothesis is rejected.

Hence it is concluded that there is difference in the level of customers' satisfactions with respect to the elements of marketing mix of organic food item.

In order to find where the difference lies we refer to the Ranks Table.

Table 2.2:-Ranks Table of Respondents satisfaction with 4P's of Marketing Mix

\begin{tabular}{|l|c|}
\hline Satisfaction & Mean Rank \\
\hline Overall Quality of the Product & 2.63 \\
\hline Packaging \& Labelling of products & 3.40 \\
\hline Health benefits after consuming & 2.21 \\
\hline Communication from seller & 3.26 \\
\hline Delivery of Product & 3.50 \\
\hline
\end{tabular}

\section{Source: Field Survey}

\section{Interpretation:}

From the Ranks Table it can be seen that "Overall quality of the product" has a mean rank of 2.63, "Packaging \& Labelling of products" has a mean rank of 3.40, "Health benefits after consuming" has a mean rank of 2.21, "Communication from seller" has a mean rank of 3.26, and "Delivery of product" has a mean rank of 3.50.

\section{Conclusion of Hypothesis:}

Hence it can be concluded that the customers are not satisfied with Delivery of Product, Packaging\& Labelling of products \& Communication from seller. Hence hypothesis Ha is proved.

Therefore hypothesis is proved Customers are dissatisfied with respect to the elements of marketing mix (4P's) of organic food items.

\section{Suggestions \\ Managerial implications}

The research study outcomes provide guidelines and suggestions to the marketers who are into the business of selling organic food. Strategies and policies can be designed for non-consumers of organic produce. Consumers are dissatisfied because of operational aspects of marketing. Therefore, strategist and marketers should stress on framing of better marketing strategies such as packaging \& labeling, availability in the retail outlets, communication and awareness of organic produce.

Retailers of organic food can segment their market and can make their marketing strategy accordingly. They can focus on their marketing strategy.

\section{Marketing mix (4p's) \\ Product}

It is very important to create regional Data bank on all aspects of organic farming such as area under organic, crop wise productivity and type of organic fertilizers data on production, what crop is cultivated in that region by the framers. Platform should be created where this information can share between buyer and seller.

Retailers should be assisted and provided with the technical expertise on how to maintain freshness and wholesomeness of their organic food items so as to attract the maximum price premium from consumers.

\section{Price}

For higher price marketers need to convince to consumers for its benefits a very strong reason for this price differentiation like cost of the health is not more than the price you pay.

\section{Place}




\begin{abstract}
Availability
The findings of the study suggest that availability is the strong predictor of intention to purchase organic food therefore organic marketers can incorporate this. Their strategy should ensure the timely availability of organic food to their consumers at proper outlets. Lacking in this strategy customer will show split loyalty in this category.

It has become necessary to conventional chains that all product groups in the organic range need to be made available all year to ensure customers are retained. This is important in order to maintain the pattern of consumer purchasing of organic food.
\end{abstract}

\title{
Promotion
}

\section{Create Awareness-}

Marketers can also design the message program to create awareness that include the information about organic, what it means how with the help of consuming of organic food they can improve their own responsibility in helping rural development \& safe guard the planet.

Consumer awareness also encouraged consumers to take some responsibility to reduce environmental damage through recycling and purchasing ecologically sound products.

Consumer awareness also encouraged consumers to take some responsibility to reduce environmental damage through recycling and purchasing ecologically sound products.

Therefore, holding awareness programs and used forums to popularize this product sector and to educate the general public are necessary for this development.

1. Direct communication can be an effective way of communication for the customers who are little aware and who are not clear what organic means. Marketers can get immediate feedback from customers; sales representative could clarify the issue promptly and clearly.

2. These customers can be contacted in stores as well as cooking demonstration and at the same time to promote the awareness of organic product.

\section{Create Interest-}

More research findings related to the difference between organic and conventional in terms of benefits, chemical residual \& nutrient difference, and Good taste can put forth in front of consumers that will increase the likeability to buy.

\section{Conclusion of The Study}

Recognition of sustainable farming is attracting the attention of society in Pune. Due to the adverse effects of conventional farming which is highly depended on artificial pesticides people understanding towards organic produce is increasing. This paper examined the motives for organic produce, study result has shown that the main reasons for not buying organic food items are its difficulty to differentiate between organic and conventional, Organic goods are not easily available in the nearby shops, lack of brand awareness, limited choice (assortment), they found it's too expensive, source of organic is not trustable. Study also identified the marketing mix of organic produce buyers are also dissatisfied with elements of marketing mix. Marketers are facing challenges in Marketing of organic produce. Study found that the customers are not satisfied with Delivery of Product, Packaging\& Labelling of products \& Communication from seller. Access to the buyer market is also restricted due to the relatively low or inconsistent demand. Consequently, ensuring a stable, predictable demand for the organic firm's products is also of paramount importance.

\section{Reference:-}

1. Grunert, S. e. (1995). Values, environmental attitudes and buying of organic food. Journal of Economic Psychology, 16, 39-62.

2. Pierce, D. (3 August 2009). Interview. (Conducted by Jay Dickieson \& Victoria Arkus).

3. Fotopoulos, C. a. (2000). Factors Affecting the Decision to Purchase Organic Food" Journal of Euromarketing. $9(3), 44$.

4. Bourn, D. a. (2002). "A comparison of the nutritional value, sensory qualities and food safety of organically and conventionally produced foods", CriticalReviews in Food Science and Nutrition. 42 (1), 1-34.

5. Beharrell, B. a. (1991). "Consumer attitudes to organic foods". British Food Journal, 93 (2), 25-30. 
6. Lin, B. P. (1986). Opinions of professional buyers toward organic produce: a case study of Mid-Atlantic market for fresh tomatoes. Agribusiness, 12 (1), 89-97.

7. Jolly, D. a. (1991). Marketing prospects for organic and pesticide-free produce. American Journal of Alternative Agriculture, 6 (4), 174-9.

8. Dettmann, R. a. (2007). (2007), "Who's buying organic vegetables? Demographic characteristics of US consumers". Journal of Food Distribution Research , 49-62.

9. Padel, S. a. (2005). Exploring the gap between attituded and behaviour. British Food Journal, 107 (8), 606-625.

10.Zanoli, R. B. (2004). The European Consumer and organic Food. Organic Marketing Initiatives and Rural Development. British Food Journal, 4. 